\title{
Is Risk Differentiation on European Insurance Markets in Danger
}

Citation for published version (APA):

Faure, M. G. (2007). Is Risk Differentiation on European Insurance Markets in Danger. Maastricht Journal of European and Comparative Law, 14, 83-100. https://doi.org/10.1177/1023263X0701400104

Document status and date:

Published: 01/01/2007

DOI:

10.1177/1023263X0701400104

Document Version:

Publisher's PDF, also known as Version of record

Document license:

Taverne

Please check the document version of this publication:

- A submitted manuscript is the version of the article upon submission and before peer-review. There can be important differences between the submitted version and the official published version of record.

People interested in the research are advised to contact the author for the final version of the publication, or visit the DOI to the publisher's website.

- The final author version and the galley proof are versions of the publication after peer review.

- The final published version features the final layout of the paper including the volume, issue and page numbers.

Link to publication

\footnotetext{
General rights rights.

- You may freely distribute the URL identifying the publication in the public portal. please follow below link for the End User Agreement:

www.umlib.nl/taverne-license

Take down policy

If you believe that this document breaches copyright please contact us at:

repository@maastrichtuniversity.nl

providing details and we will investigate your claim.
}

Copyright and moral rights for the publications made accessible in the public portal are retained by the authors and/or other copyright owners and it is a condition of accessing publications that users recognise and abide by the legal requirements associated with these

- Users may download and print one copy of any publication from the public portal for the purpose of private study or research.

- You may not further distribute the material or use it for any profit-making activity or commercial gain

If the publication is distributed under the terms of Article $25 \mathrm{fa}$ of the Dutch Copyright Act, indicated by the "Taverne" license above, 


\title{
IS RISK DIFFERENTIATION ON EUROPEAN INSURANCE MARKETS IN DANGER?
}

\author{
Michael FAure*
}

\begin{abstract}
The paper deals with the importance of risk differentiation on insurance markets. It is argued that a tendency towards a prohibition of risk differentiation supported by the equality principle may endanger the insurability of particular risks. However, Council Directive 2004/113/ECC implementing the principle of equal treatment between women and men in the access to and supply of goods and surfaces still provides sufficient scope for insurers to apply risk differentiation. Examples are given from traffic insurance and flooding insurance to demonstrate that also insurers themselves sometimes underestimate the importance of risk differentiation.
\end{abstract}

Keywords: Insurance, Liability, Risk differentiation, Non-discrimination, Moral hazard, Solidarity, Verzekering, Aansprakelijkheid, Risicodifferentiatie, Moreel risico, Solidariteit, Assurance, Responsabilité civile, Différentiation des risques, Aléa morale, Solidarité

\section{\$1. INTRODUCTION}

Insurers today find themselves in troublesome times. The number of catastrophic events has been on the rise, and so in turn have the demands of society on insurers to provide adequate compensation. If they fail to do so, insurers may be criticized for being unable to furnish society with the cover it expects. In this respect, insurers are increasingly reminded of their social responsibility. The notion of socially responsible governance has also reached the insurance world. Moreover, even in cases in which cover can be

Michael Faure is professor of comparative and international environmental law at Maastricht University and Academic Director of the Maastricht European Institute for Transnational Legal Research (METRO). I am grateful to the participants in the joint conference between the Geneva Association for the Study of Risk and Insurance and the European Association of Law and Economics (Berlin, 16-17 June 2005) and to two anonymous referees for useful comments on an earlier version of this paper. 
provided, insurers sometimes apply measures ex post which are seen as punitive by the insured, such as increasing the premium or even excluding individuals from cover. Also in this respect there exist possible objections that this is in conflict with the insurers' obligation toward socially responsible governance.

It seems that traditional insurance instruments like risk differentiation, which were always deemed necessary to make risks insurable, are also under serious attack in the media as well as at policy level. ${ }^{1}$ This is especially true of risk differentiation on the basis of gender, race, age or sexual preference. ${ }^{2}$ It has often been argued that while such a differentiation of risks may be necessary from an insurance economic point of view, it may collide with basic legal principles like the equality principle and the prohibition of discrimination.

Historically, lawyers and policymakers have alwayshad difficulties with discrimination in insurance policies going too far and may, from a policy perspective, have good reasons to distrust discrimination. Hence, they increasingly require insurers to provide allinclusive cover, often invoking the notion of solidarity to justify this requirement: good risks should be 'solidaire' with bad risks and thus a discriminatory differentiation should be avoided. The reason, according to a recent paper by Thiery and Van Schoubroeck, is that lawyers and insurers have profoundly different views on the concept of fairness in insurance classification. ${ }^{3}$

In this paper I would like to examine a tendency at policy level and in the law to prevent insurers from exercising basic ideas of insurance economics, such as classification and differentiation of risks. The importance of risk differentiation for the insurability of risks will be recalled and several examples of policy trends will be discussed in order to show that these may come into conflict with basic economic principles. In addition to providing examples of these potential conflicts, the point will be made that certain trends in policy and legislation may have adverse effects at the normative level, meaning that they may render certain risks uninsurable or could even lead to an increase in the accident risk (especially in the area of liability insurance). The paper thus attempts to add to the existing literature by bridging the legal literature based on the equality principle and the

1 See in this respect more particularly the special issue on the equality principle in 13 MJ 3 (2006) and for an application to insurance especially the contribution by E. Caracciolo Torella, 'The principle of gender equality, the goods and services directive and insurance: a conceptual analysis', 13 MJ 339 (2006).

2 See on this issue from a legal perspective J.H. Gerards et al, Genetic Discrimination and Genetic Privacy in a Comparative Perspective, (Intersentia, 2005) and the papers contained in the special issue 'Thirty years of EU sex equality law' of the Maastricht Journal of European and Comparative Law (2005), 305493, as well as L. Waddington and M. Bell, 'More equal than others: distinguishing European Union Equality Directives', 38 C.M.L.Rev. 587 (2001), and see from an economic perspective M. Hoy and P.J. Lambert, 'Genetic Screening and Price Discrimination in Insurance Markets', 25 Geneva Papers on Risk and Insurance Theory 103 (2000).

3 Y. Thiery and C. Van Schoubroeck, 'Fairness and Equality in Insurance Classification', 31 The Geneva Papers on Risk and Insurance 191 (2006). 
economic literature stressing the need for risk differentiation in insurance markets. The extent to which these conflicting views can be reconciled will be examined.

The paper will be structured as follows: after an introduction (1) basic insurance theory will be summarized to show that risk differentiation is absolutely necessary as a condition for insurability (2). In this respect a distinction between so called risk solidarity and distributive solidarity will be drawn. Next I will discuss various policy trends that have the potential to contravene principles of risk differentiation. First, Council Directive 2004/113/EEC implementing the principle of equal treatment between women and men in the access to and supply of goods and services will be discussed. ${ }^{4}$ This important Directive also applies to the insurance sector and effectively prohibits differentiation based on elements such as sex. The arguments of the European Commission in favour of and of the insurance world against this proposal will be considered (3). We will then turn our attention to the situation of traffic accidents in which there exists compulsory insurance, where the argument is often made that a full risk differentiation should not be exercised, as this would preclude certain bad risk individuals from engaging in certain activities. Therefore, the question arises as to whether risk differentiation should still be applied to the full extent in compulsory insurance or, if this is not possible, whether alternative compensation mechanisms should be used (4). An example of an incorrect use of the concept of distributive solidarity in insurance policy concerning flooding will then be presented. Insurers in the Netherlands, for instance, have argued against risk differentiation and in favor of compulsory cover on the ground that without such compulsory cover the flooding risk would be uninsurable due to adverse selection. The question is therefore whether adverse selection necessitates a regulatory intervention requiring compulsory cover and, at the same time, largely restricting risk differentiation (5). After having discussed these three examples of evolution in practice and policy, where a conflict may exist with the traditional insurance economic principles of risk differentiation, a few concluding remarks will be formulated (6).

\section{§2. PRINCIPLES OF PRIVATE INSURANCE}

The literature shows that insurance is a phenomenon that involves similar risks being brought together into risk groups with an insurance company which, because many similar but unrelated risks are covered at the same time, can spread these risks over a larger number of insured. Risk spreading creates solidarity between the members of risk pools. That solidarity, however, is referred to as risk solidarity. It simply means that comparable risks are separated into similar risk groups as a result of which they de facto carry the risks jointly. Of course, there exist two significant dangers that pose a constant threat to the insurability of risk solidarity in insurance. These are, on the one hand,

4

OJ L.373-37 of 21 December (2004). 
the renowned danger of moral hazard and, on the other, that of adverse selection. Yet, though these phenomena are indeed well known, they remain of great importance for the understanding of certain recent tendencies.

\section{A. MORAL HAZARD}

Given risk aversion, liberating the potentially insured from risk by means of insurance can increase their utility. However, the insurance system suffers from the clear drawback that if fully covered, the insured will behave differently precisely because $s /$ he is no longer exposed to risk. Of course, there are many possible remedies to cure this moral hazard risk, as has been indicated in the literature. ${ }^{5}$ The best solution to moral hazard is to control adequately the behaviour of the insured, using policy and premium conditions if necessary; the second best solution is to partially expose the insured to risk through, inter alia, a deductible or by limiting the scope of cover. In those cases one can see a risk differentiation. ${ }^{6}$ However, a detailed differentiation of risks will be too costly in practice. ${ }^{7}$ This is certainly the case with small consumer risks. Therefore, risk differentiation takes place at a collective rather than an individual level. This is precisely what the classification of risks is. The examples are well known: younger drivers pay higher premiums than older ones. Smokers receive less attractive conditions on life insurance cover than non-smokers. As such, this classification of risks is an essential instrument in the fight against moral hazard and thus also a precondition for increasing insurability of risks. It is immediately clear that if one argues against a classification of risks (on the basis of distributive solidarity), this may endanger the insurability of risks, precisely because such a classification may be necessary to keep them insurable. Moreover, risk differentiation serves to provide incentives for potential injurers to take preventive measures. Thus, risk differentiation may be considered socially desirable or even necessary. Within the context of liability insurance (again), inadequate differentiation could increase the accident risk.

The first conclusion therefore appears relatively simple: insurance is based on risk solidarity and not on distributive solidarity. Hence a tendency to reject differentiation on the basis of distributive solidarity may prove detrimental. On the one hand, this may endanger the insurability of risks; on the other, it may increase the accident risk in liability insurance. From society's point of view, it is arguable that allowing insurers to

See inter alia S. Shavell, 'On Moral Hazard and Insurance', 93 Quarterly Journal of Economics 541 (1979).

6 See further M. Spence and R. Zeckhauser, 'Insurance, Information, and Individual Action', 61 American Economic Review 380 (1971), and S. Rea, 'The Economics of Insurance Law', 13 International Review of Law and Economics 145 (1993).

7 See S. Bohrenstein, 'The Economics of Costly Risk Sorting in Competitive Insurance Markets', 9 International Review of Law and Economics 25 (1989). 
differentiate as much as possible would be beneficial for the reasons mentioned, provided the benefits of further differentiation outweigh the costs.

\section{B. ADVERSE SELECTION}

The same conclusion also applies to the second danger which equally threatens all insurers, namely adverse selection. Adverse selection is a product of the information asymmetry problem discussed by Akerlof in his seminal paper on the 'market for lemons'. Akerlof pointed to the fact that when information between contracting parties is spread asymmetrically, undertakings do not have any incentive to provide high quality goods and services as consumers cannot recognize this quality and are therefore unwilling to pay the corresponding price. Thus, only products of average quality will be placed on the market. In the end, the information asymmetry could lead to a downward spiral causing the overall quality to decrease. Applied to insurance, the poorly informed is the insurer. The insured knows whether he is a good or a bad risk and therefore what his demand for insurance is. Adverse selection therefore corresponds to the problem that insurance will of course be most attractive to those who are aware that they might have a high demand for it. In this respect, Arrow has provided the example of health insurance. ${ }^{9}$ In his view, this will always be more attractive to the somewhat older citizen who worries about his health and fears high medical costs than to the young and healthy who do not yet envisage any infirmity. ${ }^{10}$ Further, according to insurance economics, there can only be one solution to adverse selection: a detailed differentiation of risks whereby risk pools are defined as clearly and as small as possible. In fact, this means insurers would have to acquire information about the insured, and consequently should 'punish' bad risks with high premiums and 'reward' good risks with lower premiums. Hence the remedy to adverse selection that is provided in the literature is, once again, a differentiation (and thus in a certain sense an individualization). ${ }^{11}$

$8 \quad$ G. Akerlof, 'The Market for “Lemons”: Quality, Uncertainty at the Market Mechanism', 84 Quarterly Journal of Economics 488 (1970).

9 See K. Arrow, 'Uncertainty and the Welfare Economics of Medical Care', 53 American Economic Review 941 (1963), and M. Pauly, 'The Economics of Moral Hazard: Comment', 58 American Economic Review 531 (1968).

10 K. Arrow, Aspects of the Theory of Risk-Bearing (Yrjö Jahnsson Saatio, 1965).

11 For the basic ideas, see K. Crocker and A. Snow, 'The Theory of Risk Classification', in G. Dionne (ed.), Handbook of Insurance, (Kluwer Academic, 2000), 245, and M. Hoy, 'Categorizing Risk in the Insurance Industry', 97 Quarterly Journal of Economics 321 (1982). 


\section{RISK DIFFERENTIATION: NO LUXURY, BUT ABSOLUTELY NECESSARY}

From the above theoretical expose it follows that risk differentiation in insurance is absolutely necessary and certainly should not be viewed as superfluous. It is not only necessary to keep risks insurable but also, within the context of liability insurance, to reduce moral hazard and thus to reduce the accident risk. However, practice has also shown the importance of risk differentiation. In this respect the warnings of George Priest must be recalled. He explained in the Yale Law Journal in 1987 that the liability and insurance crisis that hit the US in the eighties was primarily caused by adverse selection. ${ }^{12}$ American insurers were apparently incapable of sufficiently individualizing risks and therefore of distinguishing between good and bad risks. As a result they charged average premiums, for instance in the area of medical malpractice. The effects predicted by theory did in fact materialise: relatively speaking, the average premiums were too high for the good risks. As a result, they systematically left the risk pools. In turn, the premium for the risks that remained in the pool had to be increased once more, and the new good risks again left the pool. This led to the well-documented downward spiral that resulted in certain risks, more particularly in this area of medical malpractice, becoming de facto uninsurable. The conclusion drawn by Priest, which is still of importance today, is clear and simple: ${ }^{13}$ if insurers wish to keep risks insurable they should use all available cost effective mechanisms to differentiate risks. Accordingly, regulatory interventions restricting the scope for risk differentiation should be avoided in principle, as they might lead to adverse selection. The social welfare implications of regulations that prevent insurers from making full use of risk classification are sometimes referred to as regulatory adverse selection. ${ }^{14}$

In later research, George Priest pointed to the fact that empirical research has also indicated that risk segregation is absolutely necessary to reduce accident rates. According to Priest, regimes that allow for insurance premium discrimination have lower accident rates than those that limit risk segregation. ${ }^{15}$ He quotes research by Rose Ann Devlin concerning the situation in Quebec, where a prohibition of insurance discrimination on the grounds of age, sex, criminal record and accident history led to an increase of $9.6 \%$ in fatal accidents, $26.7 \%$ in bodily injury claims and $5.3 \%$ in property damage claims.

12 G. Priest, 'The Current Insurance Crisis and Modern Tort Law', 96 Yale Law Journal 521 (1987).

13 See on these general principles inter alia J.P.H. Six, 'Maatschappelijk Verantwoorde Voor- en Naselectie', 3 Aansprakelijkheid Verzekering \& Schade 112 (2004).

14 For a further analysis of the social welfare implications of limits on risk classification see Hoy, 'Categorizing Risk in the Insurance Industry', M. Hoy, 'The Impact of Imperfectly Categorizing Risk on Income Equality and Social Welfare', 17 Canadian Journal of Economics 557 (1984) and M. Hoy, 'Risk Classification and Social Welfare', 31 Geneva Papers on Risk and Insurance 245 (2005). 
This followed the adoption of a non-discriminating no fault plan. ${ }^{16}$ Of course, it is not only George Priest who has highlighted the benefits of insurance discrimination and segregation. Theoretical support for the importance of segregation in insurance markets has also been provided, for example, in a paper by Crocker and Snow, who demonstrate that discrimination in insurance contracts enhances efficiency. The conclusion would only differ if (as indicated above) categorization led to non-negligible resource costs. ${ }^{17}$ Of course, this complies with the statement above that risk differentiation is efficient only when the marginal costs of further differentiation outweigh the marginal benefits of increased deterrence. However, the analysis of Crocker and Snow also clearly shows that prohibiting discrimination on equity grounds (the crucial issue discussed in this paper) necessarily imposes efficiency costs in addition to costs of enforcement. Hence they conclude: 'choice of policy should not proceed as if the equity objective could be achieved without loss of efficiency.' 18

Of course, the notion of risk differentiation is not without its critics. First of all, some critical economists have argued that the efficiency costs of prohibiting risk classification are much lower than commonly stated and that risk classification can be socially wasteful if it is merely selective. ${ }^{19}$ Moreover, the scope for risk differentiation is also constrained by principles of insurance law. The notion of social corporate responsibility, to which insurers equally adhere, does at least imply that general principles need to be respected when applying risk differentiation. For instance, if an insured individual files numerous claims with an insurer and, as a result, the insurer decides to terminate the contractual relationship with the insured, this decision should of course be motivated and notified to the insured well in advance, so that they can at least take the necessary steps to seek cover elsewhere. The scope for risk differentiation will therefore always be conditioned by legal principles and notions of equity. However, the point remains that, according to these principles, risk differentiation must still be used to keep risks insurable and to decrease the accident risk.

16 See Priest, 'The Government, the Market, and the Problem of Catastrophic Loss', 236.

17 K. Crocker and A. Snow, 'The Efficiency Effects of Categorical Discrimination in the Insurance Industry', 94 Journal of Political Economy 321 (1996).

18 See Crocker and Snow, 'The Efficiency Effects of Categorical Discrimination in the Insurance Industry', 339.

19 See S.A. Rea, 'Insurance Classifications and social Welfare', in G. Dionne (ed.), Contributions to insurance economics, (Kluwer Academic Publishers, 1992), 377, R. Schwarze, 'Risk Classification and public policy', 31 The Geneva Papers on Risk and Insurance 187 (2006), and R. Schwarze and T. Wein, 'Is the market classification of risk always efficient? Evidence from German third party motor insurance', http://www.lse.ac.uk/collections/carr/pdf/disspaper32.pdf, February, 1-23 2005. 


\section{RISK SOLIDARITY VERSUS DISTRIBUTIVE SOLIDARITY}

It follows that there appears to be little room for applying a notion of distributive solidarity to private insurance, especially if one holds that this notion would entail imposing a duty on insurers to provide all-inclusive cover while, at the same time, preventing them from adequately differentiating risks. On the contrary, insurance is based on the notion of risk solidarity, which simply means that within (preferably small) risk pools the risk is shared between the various participants in that pool. Therefore, insurers should in principle construct risk pools which are as small as possible through adequate risk differentiation. ${ }^{20}$ From a legal perspective this would mean that insurers should be given the right to refuse certain risks, for example, if they do not like the risk profile of a certain candidate for insurance. Indeed, such a refusal serves as an instrument to control moral hazard and adverse selection. A duty to accept certain risks, which is sometimes defended on the ground that insurers should provide universal services, is therefore incompatible with principles of private insurance. In the same way, insurers should also be granted the possibility to end cover, say, because it is found that a given insured has called on the particular policy too often.

However, as mentioned above general principles of law and equity must also be respected when applying risk differentiation. One may of course enquire as to the exact meaning of the latter. If a refusal to provide cover or the termination of a policy seems completely arbitrary and cannot be justified by the need for an adequate risk differentiation, it is arguable this might constitute an abuse of law. However, more questionable are other cases in which a far reaching differentiation of risk might collide with legal principles. Indeed, it is often held in today's legal discourse that a far reaching differentiation of risks violates principles of law and equity. Again, the notion of distributive solidarity provides the basis for this claim, as well as for the argument that some citizens should not be excluded from cover or that premiums between insured should not differ to a large extent. ${ }^{21}$ Hence, I will now address certain cases where conflicts could arise between legal principles, often based on distributive solidarity, as well as the economic demand of risk differentiation related to the notion of risk solidarity. ${ }^{22}$

\footnotetext{
20 This is referred to as 'chance solidarity' by Thiery and Van Schoubroeck, 'Fairness and Equality in Insurance Classification', 195-196.

21 See in that respect the contribution by Thiery and Van Schoubroeck, ibid.

22 See on this issue equally W.P.J. Wils, 'Insurance Risk Classifications in the EC: Regulatory Outlook', 14 Oxford Journal of Legal Studies 449 (1994).
} 


\section{§3. RISK DIFFERENTIATION VERSUS EQUALITY PRINCIPLE}

The first example concerns the fact that some question whether a too far-reaching differentiation and classification of risk would violate certain general principles of law, such as the equality principle. ${ }^{23}$ Indeed, an unavoidable consequence of a classification of risks in private insurance is that higher risks will pay a higher premium than lower risks. In order to find out whether a person constitutes a high or a low risk, the insurer, for instance in the context of a life insurance, will ask all kinds of personal questions to the insurance candidate. Yet some maintain that it is unacceptable for insurers to discriminate according to age, race, gender or sexual preference. In this respect, the Council Directive implementing the principle of equal treatment between men and women in the access to and supply of goods and services ${ }^{24}$ is of particular importance. This Directive also applies to the insurance sector. This was of course recognized by the insurance sector, which strongly objected to the draft of the proposal. The arguments of the insurers are discussed (and mainly rejected) in the motivation of the explanatory memorandum by the Commission which can be found in the proposal for a directive. ${ }^{25}$ The European Commission held:

An exception to the general absence of differential rules based on sex is found in the context of insurance. It is common for insurance to be offered on different terms to women and to men. Actuarial factors are broken down by sex in order to evaluate a risk of insuring men and women separately in various parts of the insurance market, but especially in life, health and car insurance and in the calculation of annuities. The factors taken into consideration include variations in average life expectancy, but also different patterns of behaviour (particularly in car insurance) and consumption (in health insurance).

However, insurance companies in different Member States use a wide variety of tables which are updated more or less regularly and which, in certain cases, lead to different results for men and women. In France, for example, it is common practice to apply unisex tariffs to men and women in private health insurance. The same is true in the United Kingdom (though sex differences are applied in critical illness insurance). In Germany, however, insurers differentiate between men and women. In France, similar differences of approach arise in the areas of term life insurance and pension annuities, where some insurers use unisex tables, while others tend to calculate contributions and annuity payments on the basis of tables showing life expectancy

23 G. Schoorens, 'Segmentering en Discriminatie', in H. Cousy et al, Competitiviteit, Ethiek en Verzekering, (Maklu, 1998), 230-232 and see Y. Thierry, 'De Anti-Discriminatiewet: Verzekeren Over Dezelfde Kam?', 8 Tijdschrift voor Belgisch Handelsrecht 646 (2003), and C. Paris, Les Dérives de la Segmentation en Assurances, (Larcier, 2005) and B. Weyts, 'Verzekeraars en de Anti-Discriminatiewet', 85 Nieuw Juridisch Weekblad 1082 (2004). For a recent overview of case law and legal doctrine in this respect, see Thiery and Van Schoubroeck, 'Fairness and Equality in Insurance Classification' and for an application to Belgian law see C. Van Schoubroeck and Y. Thiery, 'Discriminatie en Verzekering', 70(7) Rechtskundig Weekblad 263 (2006-2007). 
according to sex. In the area of car insurance, insurers in some Member States (e.g. the United Kingdom and Ireland) apply a strong differentiation in the rates applied to (especially young) men and women, whereas insurers in others (e.g. Sweden) do not. It is therefore possible to adopt these approaches without affecting the financial viability of the companies.

In this context, some stakeholders argue that different actuarial calculations for determining premiums, benefits and annuities for insurance products related to life expectancy must be considered as sex discrimination, as sex is not the dominant factor in determining life expectancy.

The insurance industry argues that private insurance cannot be compared to statutory insurance, in particular because it has little control over the balance of men and women in the schemes. It points out that the prices and benefits it fixes for men and women reflect the real risk the insurance companies carry for each of the insurance products they offer, and that to interfere in that calculation would result in an artificial distortion of the market, meaning some products would no longer be economically viable because the risk would be out of proportion to the income generated. This would be the case, for example, in health insurance and annuities insurance for men, and life and car insurance for women, as members of the sex required to pay a premium that is proportionately higher than their personal risk would be discouraged from taking out insurance, while members of the sex required to pay a lower rate than demanded by the real level of risk would be encouraged to do so, creating a situation in which the insurance company may not be able to meet its underwriting liabilities. The industry argues moreover that the tables it uses reflect the reality of the life expectancy of women and men, that they are regularly updated and that a public supervisory authority generally approves them.

\section{The Commission believes that these concerns are not justified:}

Insurance companies enjoy freedom to set tariffs within the limits of community law as laid down in the treaty and in the various Council and European parliament directives on life and long-life insurance. All insurance is based on the pooling of risk and the solidarity which is created between the insured. Currently, insurers decide for themselves how they wish to define the pool of risk. Many have concluded that men and women should be divided in two separate pools and that the risks they face should not be shared.

However, equal treatment for men and women is a fundamental right and the Commission believes that the freedom to set tariffs must be subject to that right. The separation of men and women into different pools leads to an unjustified difference of treatment and a resulting disadvantage for one sex or the other. The practice must be judged to be discriminatory and the legislator should therefore take action to prohibit it. 
The Commission concludes therefore that differences of treatment based on actuarial factors directly related to sex are not compatible with the principles of equal treatment and should be abolished.

This quote elegantly illustrates the very problems and conflicts referred to above. There appear to be two major difficulties with the reasoning of the Commission. First, the Commission does not draw any distinction whatsoever between those risks where the insured himself can take action to influence the risk (as with car insurance), and those where he is less able to do so (as, at least to a certain extent, with life insurance). If the insured can influence the risk, moral hazard comes into play and the conclusion is simple: if a risk differentiation is rejected as a discriminatory measure, an increase of the accident risk can be expected. In this respect one can, for instance, point to a recently published empirical study showing that the introduction of compulsory car insurance in the US led to a serious moral hazard problem as a result of which the accident risk seriously increased. ${ }^{26}$ Denying the possibility of differentiating risk (e.g. in car insurance) can thus lead to an increase in the accident risk. The issue is possibly different in situations where the insured has little influence over accident risk and thus moral hazard plays a less important role. ${ }^{27}$ This may be the case with life insurance. To be sure, an insured can also influence his life expectancy, e.g. through smoking or drinking habits (and in those cases risk differentiation should remain possible), but the point remains that an insured has no influence for example over their gender or age. Nevertheless these elements lead to an insured being placed in a 'bad risk' category based on statistics. At least in such cases, in which the elements of risks are not related to the behaviour of the insured, it is arguable that a forced distributive solidarity of good and bad risks (as proposed by the Commission) would not lead to an increase of the accident risk. ${ }^{28}$ The problem, however, is that in its explanatory memorandum the European Commission does not distinguish between these different situations at all. Moreover, even if there were no moral hazard, the above-mentioned risk of adverse selection could still emerge where some groups did not pay the actuarially fair premium. Indeed, if insurers are prevented from differentiating risks, the average premium for the good risks will be relatively high. Insurance may become less attractive for them, and the reverse is true as well: if a risk differentiation is prohibited, insurance will always be more attractive to higher risk individuals and thus adverse selection will emerge.

26 A. Cohen and R. Dehejia, 'The Effect of Automobile Insurance and Accident Liability Laws on Traffic Fatalities', 47 Journal of Law and Economics 357 (2004).

27 These are referred to in the literature as the difference between the immutable and the behavioural characteristics, although Hoy indicates that even seemingly behavioural decisions (like smoking) may also be influenced by other genes (an immutable characteristic). See Hoy, 'Risk Classification and Social Welfare', 262-263. 
However, in addition to these efficiency arguments (based on the necessity of differentiating risks in order to reduce the accident rate and to remedy adverse selection), there is also a second problem with the Commission's argument, namely that forced solidarity will lead to a negative redistribution from good to bad risks.

The insurers were thus justified in their reply to the Commission: denying them the right to differentiate risks would lead to relatively low premiums for bad risks and relatively high premiums for good risks. In the absence of compulsory insurance this may, as the insurers rightly argued, lead to excess demand for insurance of the bad risks and insufficient demand for insurance of the good risks. The good risks would again leave the pool and adverse selection would follow. Even if good risks still purchased insurance cover (say, because they were forced to do so under compulsory insurance), the effect would be that good risks pay relatively high premiums and bad risks relatively low ones. In other words, good risks partially finance, and therefore cross-subsidize, bad risks. This negative redistribution could prove highly controversial.

Nevertheless, the arguments advanced by the insurers have apparently convinced the drafters of Council Directive 2004/113/EC, as an important exception is now provided for the insurance industry. Preamble 19 preceding the Directive argues, inter alia, that 'in some cases, sex is one but not necessarily the only determining factor in the assessment of risks insured. For contracts insuring those types of risks, Member States may decide to permit exemptions from the rule of unisex premiums and benefits, as long as they can ensure that underlying actuarial and statistical data on which the calculations are based are reliable, regularly updated and available to the public'. The exemptions are also only allowed if national legislation has not already applied the unisex rule. Moreover, five years after transposition of the Directive, Member States should re-examine the justification for those exemptions, taking into account the most recent actuarial and statistical data. As a result, an exception is provided for actuarial factors in Article 5 of the Directive, allowing Member States to sanction 'proportionate differences in individuals' premiums and benefits where the use of sex is a determining factor in the assessment of risk based on relevant and accurate actuarial and statistical data'.

In summary, the objections of the insurers were apparently so convincing that they were able to influence the final contents of the Directive. The result is that gender can still be used as a proxy for risk differentiation as long as accurate data show that it is indeed a relevant criterion for risk assessment.

\section{\$4. COMPULSORY INSURANCE?}

One could probably also argue that a detailed risk differentiation is not so burdensome for the insured provided it concerns voluntary insurance. Take the example of personal accident insurance. Insurers in this area are likely to give the insurance candidate a detailed questionnaire, asking him/her all kinds of questions relating to issues like 
gender, age, lifestyle and health in order to be able to judge the risk. This will enable them to draft an individualized policy and fix a corresponding premium. In this particular case, it is arguable that the potential insured may simply decide not to take the insurance cover if they object to the curiosity of the insurer.

However, one should exercise a degree of care when determining the 'voluntary' nature of insurance cover. In most countries life insurance policies are voluntary in theory. In most countries there is no regulatory duty to conclude a life insurance policy. However, it is also the case in most countries that one cannot obtain a mortgage on a house if one does not at the same time take out a life insurance policy. Hence in certain cases, including some involving so-called 'voluntary' insurance, individuals may effectively be forced to conclude such contracts, in which case the option not to take out that particular policy no longer appears very realistic. ${ }^{29}$

Of course, the same applies in cases where there exists an outright duty to purchase insurance cover. There are many examples of this in all legal systems. It is often argued in this respect that a detailed risk distribution by the insurer could ultimately prevent certain citizens from engaging in certain activities, especially if the insurer decided not to provide cover to citizens for specific risks on the basis of risk differentiation. If all other insurers took the same decision, it would effectively mean that a given citizen (natural person or enterprise) would not be able to engage in a particular activity. This is often considered a problematic consequence of risk differentiation in compulsory insurance, particularly in light of the idea that there should be a universal right to the services of insurers.

Again, from an economic perspective the effects of risk differentiation on compulsory insurance are not that straightforward. Insurers may indeed choose to cover only the best risks, which could leave bad risks without any insurance protection at all. If risk averse individuals cannot obtain insurance protection, this may not increase social welfare either. ${ }^{30}$ This problem may arise especially where it concerns factors that cannot be controlled or influenced by the insured. Yet, excluding some individuals is a normal consequence of compulsory insurance: if certain insured have a particularly bad risk profile, they will not be able to obtain cover or they will only be covered at an exceptionally high premium. In some cases this can indeed mean that some individuals or enterprises will not engage in the risky activity for which a duty to seek insurance cover exists. At the same time one could argue that, from society's perspective, this is a desirable effect of compulsory insurance and risk differentiation, more particularly in cases where - as we have argued above - the risk can be influenced by the behaviour of the insured. Nevertheless, and somewhat surprisingly, one often hears arguments to the contrary. Take the example of compulsory liability insurance for motor vehicles.

29 See in this respect also Hartlief, 'Verzekerbaarheid van Aansprakelijkheid in het Perspectief van Maatschappelijk Verantwoord Ondernemen', 242.

30 Schwarze, 'Risk Classification and public policy', refers to this phenomenon as an adverse selection 'on the side of the insurers'. 
Clearly, there exist bad drivers who cause so many accidents that they effectively become every insurer's nightmare. These are the type of drivers who apparently cannot be forced into decent driving behaviour, regardless of the type of experience rating system or premium increases. If insurers charged the actuarially fair premium, being the premium that represents the real risk constituted by those individuals, the premium would be excessively high. As a consequence, the particular insured could decide not to engage in that particular activity, that is driving a car, any longer. That could be considered a desirable effect. Insurance then causes the individual concerned to change their activity. Society will be safer because the particular individual will not use the car any longer. Nevertheless, it is often argued that this would be an unacceptable consequence. If an excessively high premium is charged, certain persons (the high risk individuals) would no longer be able to drive a car. Here one clearly sees the trade-off between the insurance economic need for risk differentiation on the one hand, and the desire to provide risk averse individuals with cover on the other. Hence, legal and other constructions are often introduced, the main aim of which is to counter the effects of risk differentiation. In the Netherlands, for instance, the real actuarially fair premium for motorcycle riders is not charged, as this would mean that the premium would be considered unbearable for the risky drivers who could then no longer engage in that activity. ${ }^{31}$ As a result, a lower than actuarially fair premium is charged. A similar construction is employed in many countries where various instruments are invented to keep the high risk car drivers on the road. For instance, in countries like Belgium (and the Netherlands), insurers participate in various pool constructions which provide cover to the bad drivers that have been rejected by all other insurance companies. ${ }^{32}$

Again, one could of course criticize these constructions as they result in bad drivers being kept on the road. However, a detailed risk differentiation and the resulting refusal of insurers to cover those risks could ultimately lead to particular individuals being excluded from certain activities. Insurers maintain that it is not their duty to exclude bad drivers, and so they cooperate voluntarily in these arrangements. Indeed, some literally hold that it should not be up to the insurers to decide who is allowed on the road and who is not. ${ }^{33}$ However, it is doubtful that these arrangements, which keep dangerous drivers on the road, are in society's interest.

Whatever the (mostly political) reasons may be for either charging less than the actuarially fair premium to risky drivers or organizing pool constructions (where

31 See Hartlief, 'Verzekerbaarheid van Aansprakelijkheid in het Perspectief van Maatschappelijk Verantwoord Ondernemen', 242.

32 In the Netherlands this construction was first referred to as 'Terminus' which was a nice name, precisely corresponding to what it was: the final station; recently the name has been changed to 'Rialto' which, in my opinion, is much too nice a word. by I.S.J. Houben, Contractdwang en Verzekering, in T. Hartlief and M.N. Mendel (eds.), Verzekering en Maatschappij, (Kluwer, 2000), 292. 
drivers can probably obtain insurance at lower than actuarially fair premiums), the value is questionable. One consequence is that someone whose activity is apparently too expensive, meaning that the expected accidents costs are so high that he cannot pay the corresponding premium, would still be allowed to continue to drive. Moreover, since this participation is possible at lower than actuarially fair premiums, this leads to an increase in the accident risk as compared to the situation where risk differentiation is simply allowed to function to the full extent. These solutions, whatever their legal basis may be, de facto lead to an increase in the accident risk. Moreover, if a lower than actuarially fair premium is charged to risky drivers, an inevitable consequence is again that a cross subsidization occurs, meaning good risks ultimately have to pay to keep bad risks on the road. These solutions, which reject a correct application of risk differentiation, therefore appear inefficient (because they increase the accident risk) and unfair (because they lead to negative redistribution).

\section{§5. FLOODING}

A further example can again illustrate the consequences of an erroneous use of the concept of distributive solidarity in insurance policy. In the 1950s, insurers in the Netherlands drafted so-called binding decisions which applied to all of their members, prohibiting them from insuring flood and earthquake risks (the latter being relatively small in the Netherlands with the exception of the area around southern Limburg). The insurers' argument was that these risks were technically not insurable and that all of their members should therefore refrain from covering them. ${ }^{34}$

However, in the 1990s it became clear that these agreements violated the conditions of Regulation 3932/92, which clearly stated that the exemption of the insurance industry from the cartel prohibition may not contain, in particular, any systematic exclusion of specific types of risk without expressly providing for the possibility of including that cover by agreement. ${ }^{35}$ It was repeated in Article 7(1)(a) of the exemption. In its report to the European Parliament, the European Commission explicitly discussed the Dutch binding decision and as a result the Dutch insurers association decided to bring its binding decision into line with Article 7(1)(a) by simply converting it into a non-binding recommendation, leaving each insurer free to extend cover to flood risks. ${ }^{36}$

As a result, a debate arose concerning the insurability of the flooding risk. During that debate the Dutch insurers claimed that flooding would constitute a serious adverse

\footnotetext{
34 See on the legal history of this Dutch flood insurance M. Faure and T. Hartlief, Nieuwe Risico's en Vragen van Aansprakelijkheid en Verzekering, (Kluwer, 2002), 183-189.

35 For a discussion of this regulation see M. Faure and R. Van den Bergh, 'Competition on the European Market for Liability Insurance and Efficient Accident Law', 9 MJ 279 (2002).

36 See M. Faure and R. Van den Bergh, 'Aansprakelijkheidsverzekering, Concurrentie en Ongevallenpreventie', in: Hartlief and M. Mendel (eds.), Verzekering en Maatschappij, 315-342.
} 
selection risk, meaning that only those with a high risk profile (for flooding) would seek insurance cover. Thus it was argued that flooding should only be insurable on the condition that all citizens be forced to take out mandatory cover for flood risks. ${ }^{37}$ It was argued that if not all individuals were forced into the insurance adverse selection would emerge, as only those with a high risk would seek insurance cover, thereby excluding the good risks. Again one recognizes the distributive solidarity argument: everyone would be forced to pay for the flood risk. The Dutch Council of State viewed the Dutch insurers' argument as ill-founded and contended that it would lead to a general increase in the burdens on citizens, which would be unacceptable. As a result of this criticism by the Dutch Council of State, the proposal was withdrawn.

This demonstrates that the adverse selection argument is used incorrectly and disguised as a distributive solidarity argument. Of course, the traditional remedy against adverse selection - risk differentiation - can be applied to flooding insurance as well. Some citizens may not have a demand for cover at all, in which case there is no point in making cover for them compulsory. Others might be exposed to the risk of flooding, for example, but the risk may be a minor one; whereas others still (i.e. those living in riskier areas) may be exposed to a higher risk. It is by no means necessary to force those who run no risk into insurance. Risk differentiation simply means that an adequate differentiation is possible between the different risks with corresponding policy conditions and differentiated premiums. ${ }^{38}$

The insurers were suggesting that the risk would only be insurable and adverse selection could only be cured if all citizens (including those facing no risk at all) were forced into the insurance. That is certainly not the case. Here the insurers were clearly failing to distinguish adverse selection from the problem that insurability requires a sufficiently large number of insured in order to create insurance capacity. If the number of individuals exposed to the catastrophic risk were too low, sufficient demand might not emerge and this could endanger the insurability of the risk. That is, however, hardly an adverse selection problem. ${ }^{39}$ The only adverse selection problem that arises is that within the group of people with a demand for insurance an adequate differentiation of risks should be applied. By differentiating risks in this way, adverse selection can be avoided without forcing those who run no risk at all to contribute financially to the risk run by others. Here again we find an example of unfair solutions being adopted on the basis of (hidden) inefficient distributive solidarity arguments, as the solution proposed by the

\footnotetext{
37 More particularly the example of France, where such a mandatory cover for disaster risk exists, played an important role in that respect. See on the case of France: M. Cannarsa et al, 'France', in M. Faure and T. Hartlief (eds.), Financial Compensation for Victims of Catastrophes, (Springer, 2006), 81-118. Financial Compensation for Victims of Catastrophes: A Comparative Legal Approach, 195-226. disasters: competition or solidarity?’, 29 World Competition 25 (2006).
} 
Dutch insurers would effectively have meant that those who constituted no risk at all would also have been forced to contribute to the particular risk. ${ }^{40}$

\section{\$6. CONCLUDING REMARKS}

In the introduction I mentioned that society today expects a lot from insurance. Not only are insurers expected to fully cover citizens against all kinds of possible risks, but increasingly they are also expected to take into account their corporate social responsibility. In the latter context, and within the framework of the universal delivery of services, it is sometimes also maintained that insurers should promote distributive solidarity and hence should only differentiate risks to a limited extent. In this contribution I have argued that although this argument may have intuitive appeal, since it allows many individuals to obtain insurance cover at reasonable prices, there are certain dangers as well. This contribution has attempted to confront the legal equality principle and the prohibition of discrimination with the economics of insurance. In fact, traditional insurance economics prescribes that insurers should bring similar risks together in risk pools which are as small as possible. From an insurance economic perspective, insurers should therefore apply the well established insurance economic principles of risk differentiation and risk classification. This is an essential pre-requisite for keeping risks insurable. If the social planner blindly stresses solidarity and, say, forces insurers to accept certain risks, this may lead not only to an increase of the accident risk (in those cases where the insured can influence the risk and thus a moral hazard problem arises), but also to a negative redistribution. However, the example of flooding insurance demonstrates that insurers have also been known to call on distributive solidarity, sometimes implicitly, in order to force those who run no risk at all to contribute to the cover of those who are exposed to the flooding risk.

Indeed, insurers should preferably align premium and policy conditions as much as possible to the individual risk posed by the insured. This is not only fair (in the sense that the premium paid by the insured corresponds to the risk run), but also a safety requirement. The notion of distributive solidarity could lead to calls to insure different risks under the same conditions. This seems highly risky. First of all, it would lead to a negative redistribution since good risks would have to subsidize bad risks. Especially where it concerns liability insurance, inadequate risk differentiation can increase the accident risk and, in the end, render the risk uninsurable. In this regard, the example of the American insurance crisis should be borne in mind. The American experience makes clear that, in extreme cases, adverse selection may become so serious that insurers are ultimately left with only the high risk individuals, leading them to withdraw from

40 Critical in this respect are also R. Schwarze and G. Wagner, 'In the aftermath of Dresden. New Directions in German flood insurance', 29 Geneva Papers on Risk and Insurance 154 (2004). 
the market. The effective uninsurability of certain risks was the result. Policymakers could learn from the American experience that risk differentiation and risk classification should be promoted in order to both increase the prevention of risks and to remedy adverse selection. Therefore, society should not expect its insurers to create equality in insurance. On the contrary, it would be in society's interest to require insurers to differentiate risks as much as possible in order to promote safety. The latter is of course especially important as far as regards liability insurance and more particularly where the insured has the capacity to influence the risk. When the latter is not the case and the differentiation concerns immutable characteristics such as age or gender, a prohibition based on equality would not affect the academic risk, but adverse selection would still occur as insurance would become less attractive for the good risks.

Of course this contribution was limited to private insurance, and in this area risk solidarity and premium differentiation are key issues. Social security has a different starting point, however, namely that distributive solidarity and an income-dependent premium are crucial. However, one also notices that private insurers are increasingly active in domains that traditionally belonged to social security, like health care insurance. Provided that general principles of private insurance (like risk differentiation) can be respected, private insurers could also play an important role in domains that traditionally belonged to social security. ${ }^{41}$

However, in that case the government has to realize that neglecting essential insurance economic principles like risk differentiation may be perilous, as it could force private insurers into a role which does not suit them, possibly resulting in an increase in the safety risk, cross-subsidization and (in extreme cases) even uninsurability. Therefore, the normative conclusion of the literature on risk differentiation is clear: it remains important for governments to endow insurers with the necessary scope to exercise their traditional tasks of risk differentiation and risk classification correctly. Council Directive 2004/113/ EC seems to have understood this message. Notwithstanding a principal prohibition of discrimination in Article 5(1), an important exception for proportionate differences in individuals' premiums is provided in Article 5(2), where the use of sex is a determining factor in the assessment of risk based on relevant and accurate actuarial and statistical data. This still provides substantial scope for an adequate differentiation of risks. 41 M. Faure, 'The Applicability of the Principles of Private Insurance to Social Health Care Insurance,
Seen from a Law and Economics Perspective', 23 Geneva Papers on Risk and Insurance 265 (1998). 